Review

\title{
The Effect of Interleukin-1 Receptor Antagonist on Arteries and Cholesterol Metabolism
}

\author{
Kikuo Isoda and Fumitaka Ohsuzu \\ Internal Medicine I, National Defense Medical College, Tokorozawa, Japan.
}

\begin{abstract}
This review summarizes both the structure and function of IL-1 receptor antagonist (IL-1Ra), and relates our new findings, particularly those obtained in IL-1Ra-deficient mice (IL-1Ra ${ }^{-/}$), to the role of IL-1Ra in arterial diseases and cholesterol metabolism. IL-1Ra'- mice show an increase in neointima-formation after arterial injury. Heterozygosity in the IL-1Ra gene against the apolipoprotein E-deficient background revealed a role for IL-1 in promoting atherogenic cell signaling and that the larger lesions of IL$1 \mathrm{Ra}^{-/-}$mice are enriched in macrophages and depleted of smooth muscle cells. Furthermore, IL-1Ra ${ }^{-/}$mice developed severe fatty livers and hypercholesteroremia following 20 weeks on a atherogenic diet compared to WT mice. Taken together, these results suggest that IL-1Ra plays important roles in restenosis after angioplasty, the development of atherosclerosis, and the metabolism of cholesterol in vivo. $J$ Atheroscler Thromb, 2006; 13: 21-30.
\end{abstract}

Key words: Interleukin-1 receptor antagonist, Inflammation, Atherogenesis, Cholesterol metabolism

\section{Introduction}

Interleukin (IL)-1 is a physiologically active factor produced and secreted by a variety of cells including those responsible for controlling immunity. Furthermore, it plays an important role in immune reactions, cell damage, and cell-proliferation $(1,2)$. IL-1 consists of two molecules, IL- $1 \alpha$ and IL- $1 \beta$, both of which exert similar but not completely overlapping biological functions mediated through the IL-1 type I receptor (IL-1RI). Another IL-1 receptor, the type II receptor (IL-1RII), has also been identified, but this receptor is not considered to be involved in signal transduction, but is rather thought to play a regulatory role as a "decoy". In addition, another member of the IL-1 gene family, IL-1 receptor antagonist (IL-1Ra), binds to IL-1 receptors without exerting agonistic activity. IL-1Ra as well as IL-1RII and the secretory forms of

Address for correspondence: Kikuo Isoda, Internal Medicine I, National Defense Medical College, 3-2, Namiki, Tokorozawa, Saitama, 359-8513, Japan.

E-mail: isoda@me.ndmc.ac.jp

Received September 26, 2005

Accepted for publication October 25, 2005
IL-1RI and IL-1RII are considered to negatively regulate IL-1 signaling (3).

The balance between IL-1 and IL-1Ra has significant effects on host responses to inflammation and infection $(4,5)$. In the immune system, IL-1 has many systemic effects in the protection of the body, being involved in fever, the response to stress, and the metabolism of insulin, lipid and bone $(6,7)$. Notably, in vascular homeostasis, IL-1 is considered one of the most potent proinflammatory cytokines acting on endothelial cells (ECs) and smooth muscle cells (SMCs) (8). IL-1 is produced from these cells as well as macrophages (M $\phi s$ ) and hepatocytes $(9,10)$. IL-1 induces the expression of surface leukocyte adhesion molecules in ECs, proliferation of SMCs, and secretion of other cytokines and chemokines from ECs, SMCs, and M $\phi s(11,12)$. These effects of IL-1 are strongly implicated in cardiovascular diseases (13-15). IL-1Ra, one of the negative regulators of IL-1 signaling, plays a role as an anti-inflammatory cytokine, similar to IL-10 and TGF- $\beta$, in acute- and chronic- inflammation of the vascular wall $(16,17)$. IL$1 \mathrm{Ra}$ is also produced by ECs and SMCs as well as M $\phi S$ for maintaining vascular homeostasis $(18,19)$. This re- 
view, focuses on the effects of IL-1Ra on atherogenesis and cholesterol metabolism.

\section{Structure of Human IL-1 Ra}

IL-1Ra was originally discovered as an inhibitor of IL-1 in the urine of patients with fever (20). A cDNA encoding the secreted form of the molecule was identified in a human monocyte library (21). Secretory IL-1Ra (sIL-1Ra) is synthesized as a 177-amino acid protein requiring the cleavage of a 25 -amino acid leader sequence prior to secretion as a variably glycosylated 152 -amino acid protein. A second cDNA coding for an intracellular form of IL-1Ra (iclL-1Ra) was cloned from a different human monocyte library (22). These two isoforms of IL-1Ra are created by alternative splicing yielding different first exons (23). The internal splice acceptor site for iclL-1Ra was located within the first exon for sIL-1Ra, near the 3' end of the sequence coding for the signal peptide. iclL1 Ra does not have a functional leader sequence and remains in the cytoplasm. The sIL-1Ra protein is produced by many cells that can synthesize IL-1. icIL-1Ra is found constitutively in keratinocytes and other epithelial cells but is also a delayed product of stimulated $\operatorname{M\phi s}(24,25)$. Neutrophils contain only sIL-1Ra mRNA, whereas fibroblasts are capable of producing the mRNA and protein for both IL-1Ra isoforms, when appropriately stimulated (26).

\section{Function of IL-1 Ra}

In spite of extensive studies on IL-1 over the past two decades, the important roles that this cytokine may play in normal biology are unclear $(27,28)$. Furthermore, it remains unknown whether the function of IL-1Ra is limited to regulating the agonistic effects of extracellular IL1 in normal biologic processes or in pathophysiological conditions. Studies on the functional consequences of overexpression or absence of expression of IL-1Ra in transgenic or knockout mice, respectively, may clarify some possible roles of this cytokine in normal biology. This review relates our new findings (obtained from IL1Ra-deficient mice (IL-1Ra-/)) about the effects of IL-1Ra on arteries and cholesterol metabolism.

\section{IL-1Ra and neointima formation after injury}

Neointimal hyperplasia is characterized by the activation, migration, and proliferation of SMCs and is associated with inflammatory mediators such as cytokines. IL$1 \beta$ is a chemoattractant and mitogen for SMCs (28) that is overexpressed at sites of the active proliferation and migration of this cell type subsequent to injury (29). Furthermore, a recent report demonstrated that IL-1RI genedeficient mice tended to develop less neointima than wildtype mice (30). In sum, these previous studies suggested that IL-1 might promote neointimal formation. However, it remained uncertain whether IL-1Ra, the endogenous inhibitor of this central cytokine, could significantly suppress this response in the vasculature. Using IL-1 $\mathrm{Ra}^{-/-}$ mice (on the C57BL/6J background) and wild-type (IL$1 \mathrm{Ra}^{+/+}$) mice, we investigated neointimal formation 3 weeks after femoral artery injury induced with an external vascular cuff. The mean intimal thickness and the intima/media ratio of IL-1 $\mathrm{Ra}^{-/-}$mice increased by $249 \%$ and $257 \%$, respectively, compared with IL-1Ra ${ }^{+/+}$mice (Fig. 1A) (31). Control immunostaining for IL-1Ra in injured vessels identified IL-1 $\beta$ and the endogenous inhibitor in the endothelium and inflammatory cells of adventitia in IL-1Ra ${ }^{+/+}$mice but not IL-1Ra'-/- mice (Fig. 1B) (31). These results suggest that IL-1Ra protein prevents inflammation of both the intima and adventitia after cuff injury. Indeed, IL-1 Ra ${ }^{-/}$mice showed an increase in the proliferating cell nuclear antigen (PCNA) index of the intima and adventitia after injury. Within the adventitia, proliferating monocytes and macrophages comprised the majority of PCNA-positive cells. Recent studies have shown that adventitial passive fibroblasts can become active myofibroblasts under conditions of adventitial inflammation $(32,33)$. On the other hand, SMCs were the predominant proliferating cell type in the intima (31). IL-1 itself is a mitogen for SMCs (28), and furthermore, a recent study showed that vascular intima formation after mechanical injury mainly involves inflammatory cells that originate from the bone marrow (34). Our study demonstrated definitively that a deficiency of endogenous IL1 Ra promotes neointimal formation, revealing a crucial role for this protein in hyperplastic responses of the vasculature. Our results may be compatible with the report that p80 IL-1 type I receptor knockout mice tended to develop a smaller (7-fold) neointimal area induced by low shear stress compared to wild-type controls (30). This report demonstrated that IL-1 modulates low shear stress-induced neointimal formation, thus providing a direct proinflammatory cytokine signaling link between biomechanical forces to a vessel wall and the remodeling response of the artery. They also concluded that specific anti-IL-1 therapy may lessen neointimal formation.

\section{IL-1Ra and atherogenesis}

Atherogenesis is a complex process in which the activation of ECs and SMCs appears to be a central theme (8). IL-1 is produced by these cells as well as $\mathrm{M} \phi$ s and hepatocytes $(9,10)$. Furthermore, stimulation and activation of ECs and SMCs by IL-1 causes a wide range of inflammatory processes within the atheroma, such as the enhanced expression of leukocyte adhesion molecules $(9,12)$, clotting factors and inhibitors of fibrinolysis (11), and chemokines (28), as well as increased proliferation of SMCs $(8,15)$, suggesting a central role for IL-1 in the development of atherosclerosis. The activity of IL-1 is 
A
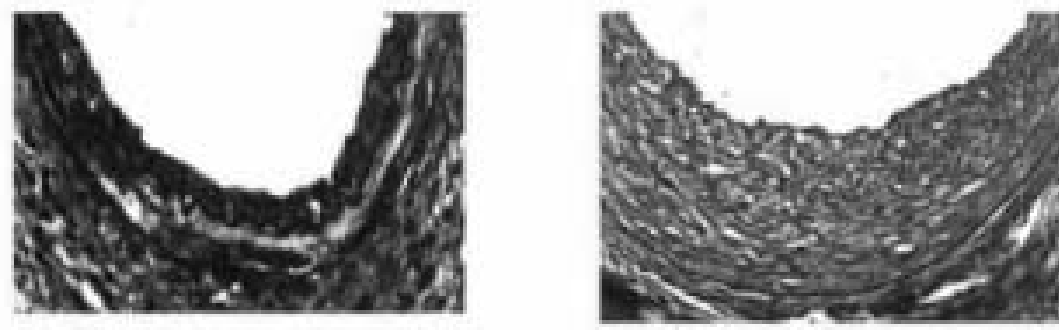

B

Fig.1. Lack of IL-1Ra promotes neointimal formation after injury

A. Histology of cuffed femoral arteries (day 21) of IL-1Ra+/+ (left) and IL-1Ra ${ }^{-/-}$(right) mice. Intimal thickness was significantly increased in IL-1 $\mathrm{Ra}^{-/-}$mice compared with IL-1 $\mathrm{Ra}^{+/+}$ mice. Sections were stained with Masson's trichrome. Original magnification $X 50$.

B. Representative photomicrographs depict immunohistochemical staining for IL-1Ra in cuffed femoral arteries of IL-1Ra ${ }^{+/+}$(left) and IL-1Ra-/- (right) mice (day 7). Boxed areas are enlarged at the bottom of the panels. IL-1Ra protein is present in both the endothelium and some inflammatory cells (arrows) in IL$1 \mathrm{Ra}^{+/+}$mice. Original magnification X 100 (upper panels) and X150 (bottom panels).
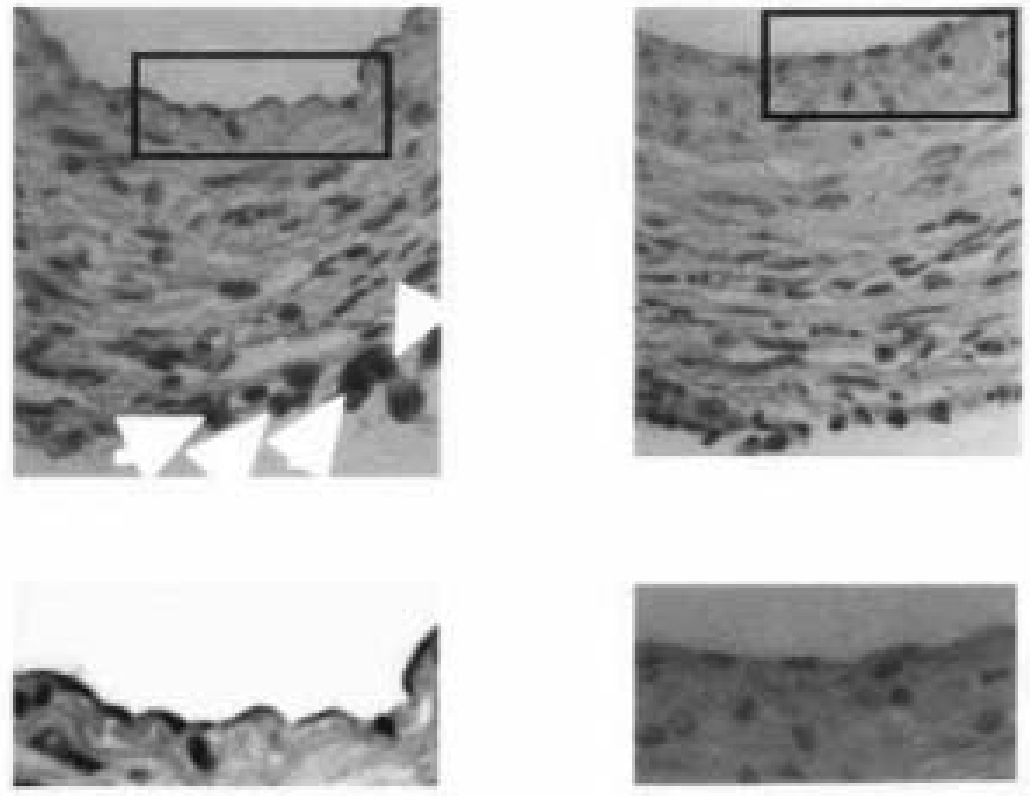

(Circulation, 108; 516-8, 2003) counter-regulated by its endogenous inhibitor IL-1Ra (15, 27) and a previous report showed that IL-1Ra is expressed in ECs and atherosclerotic lesions (18). Treatment with recombinant IL-1Ra proved an effective therapy for atherosclerosis in apoE $\mathrm{E}^{-/-}$mice (35). Furthermore, low density lipoprotein receptor-deficient (LDLR ${ }^{-/}$) mice crossed with transgenic mice expressing high levels of murine sIL-1Ra were also partially protected compared to their non-transgenic controls. In contrast, LDLR ${ }^{-/ I L-}$ $1 \mathrm{Ra}^{-/-}$mice had a tendency to develop foam cell lesions on a diet rich in cholesterol and cholate (36). Moreover, in humans IL-1Ra gene polymorphism is significantly associated with coronary artery disease (37). These findings suggest that endogenous IL-1Ra may suppress atherosclerosis. To directly answer the question of whether a deficiency of IL-1Ra promotes the development of ath- erosclerotic lesions and/or can modulate the phenotype of atheroma, we employed IL-Ra ${ }^{-/-}$mice. Using apoE ${ }^{-/-}$ mice as an animal model of atherosclerosis, we established three genotypes (IL-1 $\mathrm{Ra}^{+/+} /$apoE ${ }^{-/-}$, IL-1Rat/-/ apoE $\mathrm{E}^{-/-}$, and IL-1 $\mathrm{Ra}^{-/ /}$apoE $\mathrm{E}^{-/-}$mice) by cross-breeding. This study focused on the comparison of atherosclerotic lesions and $\mathrm{IL}-1 \mathrm{Ra}^{+/+} / \mathrm{apoE}^{-/-}$and $\mathrm{IL}-1 \mathrm{Ra}^{+/-/}$apoE ${ }^{-/-}$mice, because of the significantly leaner phenotype in IL-1Ra ${ }^{-/-}$ apoE ${ }^{-/-}$mice. Interestingly, the size of the atherosclerotic lesion safter 16 weeks was significantly increased (30\%) in IL-1 $\mathrm{Ra}^{+/-/}$apoE ${ }^{-/-}$mice compared to IL-1Ra ${ }^{+/+} / \mathrm{apoE}^{-/-}$ mice (38). Following 32 weeks, the differences in lesion size between these mice failed to achieve statistical significance (38). However, immunostaining demonstrated an $86 \%$ increase in the MOMA-2-stained area in IL$1 \mathrm{Ra}^{+/ /}$apoE ${ }^{-/-}$mice (Fig. 2A). In addition, $\alpha$-actin stain- 


\section{$\mathbf{R a}^{+/+} / \mathbf{E}^{-/-}$}

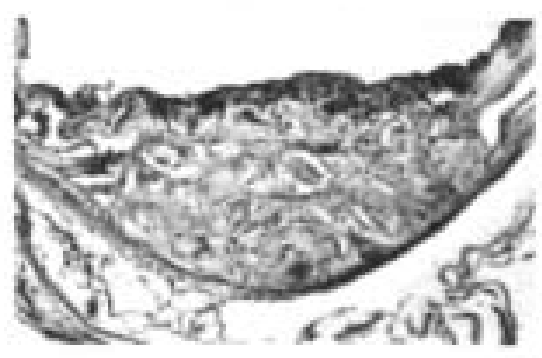

B

\section{$\mathbf{R a}^{+1-/ \mathbf{E}^{-/}}$}

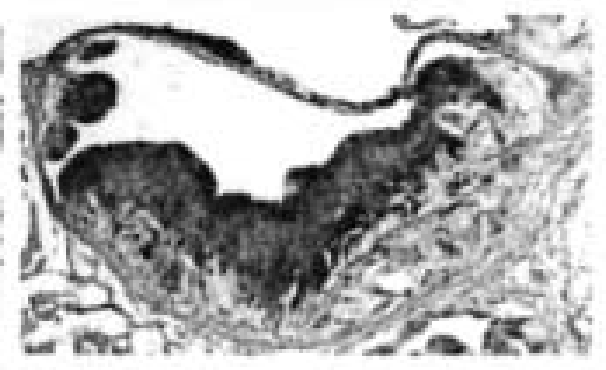

Fig.2. Deficiency of IL-1Ra modulates plaque composition in $\mathrm{ApoE}^{-/-}$mice.

A. Representative photomicrographs of sections of advanced atherosclerotic plaques (immunohistochemical staining for MOMA-2) from the aortic sinus of IL-1 $\mathrm{Ra}^{+/+}$/ apoE $^{-/-}\left(\mathrm{Ra}^{+/+} / \mathrm{E}^{-/ /}\right)$(left) and IL-1 $\mathrm{Ra}^{+/ /} / \mathrm{apoE}^{-/-}$ $\left(\mathrm{Ra}^{+/ /} / \mathrm{E}^{-/-}\right)$(right) mice at 32 weeks of age. IL-1 $\mathrm{Ra}^{+/-/ a p o E^{-/-}}$mice showed markedly increased numbers of macrophages in lesions compared with IL-1 $\mathrm{Ra}^{+/+} / \mathrm{apoE} \mathrm{E}^{-/-}$mice. Original magnification X100.

B. Representative photomicrographs of sections of advanced atherosclerotic plaques (immunohistochemical staining for $\alpha$-smooth muscle cell actin) from the aortic sinus of IL-1 $\mathrm{Ra}^{+/+} / \mathrm{apoE}^{-/-}\left(\mathrm{Ra}^{+/+} / \mathrm{E}^{-/ /}\right)$(left) and IL-1 $\mathrm{Ra}^{+/-/ a p o E^{-/-}}\left(\mathrm{Ra}^{+/ /} / \mathrm{E}^{-/-}\right)$mice (right) at 32 weeks of age. SMC numbers in the lesions in IL-1 $\mathrm{Ra}^{+/-/ a p o E^{-/-}}$mice were significantly decreased compared with those in IL$1 \mathrm{Ra}^{+/+} / \mathrm{apoE}^{-/-}$mice. Original magnification X100.

(Arterioscler Thromb Vasc Biol, 24; 1068-73, 2004)

ing in these lesions was significantly decreased (-15\%) compared to that in IL-1 $\mathrm{Ra}^{+/+} /$apoE ${ }^{-/-}$mice (Fig. 2B) (38). Our real-time polymerase chain reaction (RT-PCR) analysis revealed that deletion of IL-1Ra increases the mRNA expression of the adhesion molecules vascular cell adhesion molecule (VCAM)-1 and intercellular adhesion molecule (ICAM)- 1 in the aorta, and enhances mRNA levels of monocyte chemoattractant protein (MCP)-1 (38). These changes may contribute to the enhanced accumulation of M $\phi s$ in advanced plaques. Interestingly, IL-1 $\beta^{-/-}$/ apoE $^{-/-}$mice showed opposite results, thus demonstrating that the size of atherosclerotic lesions at the aortic

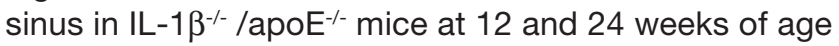
showed a significant decrease of $30 \%$ compared with that in IL-1 $\beta^{+/+} /$apoE ${ }^{-/}$mice, and the mRNA levels of VCAM-1 and MCP-1 in the IL-1 $\beta^{-/-} / \mathrm{apoE}^{-/-}$aorta were significantly reduced compared with those in the IL-
$1 \beta^{+/+} /$apoE ${ }^{-/-}$mice (39). They suggested that IL-1 $\beta$ exerts an atherogenic action by enhancing the expression of VCAM-1 and MCP-1 in the aorta. This report may support our results. Taken together, these findings suggest an important role for IL-1Ra in suppressing the development of lesions early during atherogenesis and furthermore, implicate it in the modulation of plaque composition.

\section{IL-1Ra and cholesterol metabolism during chronic inflammation}

Infection and inflammation induce an acute-phase response (APR) (40), leading to multiple alterations in lipid and lipoprotein metabolism (41). Serum triglyceride (TG) levels are increased by multiple cytokines, including IL1, IL-2, IL-6 and tumor necrosis factor (42-48), because of increased secretin of very low density lipoprotein 


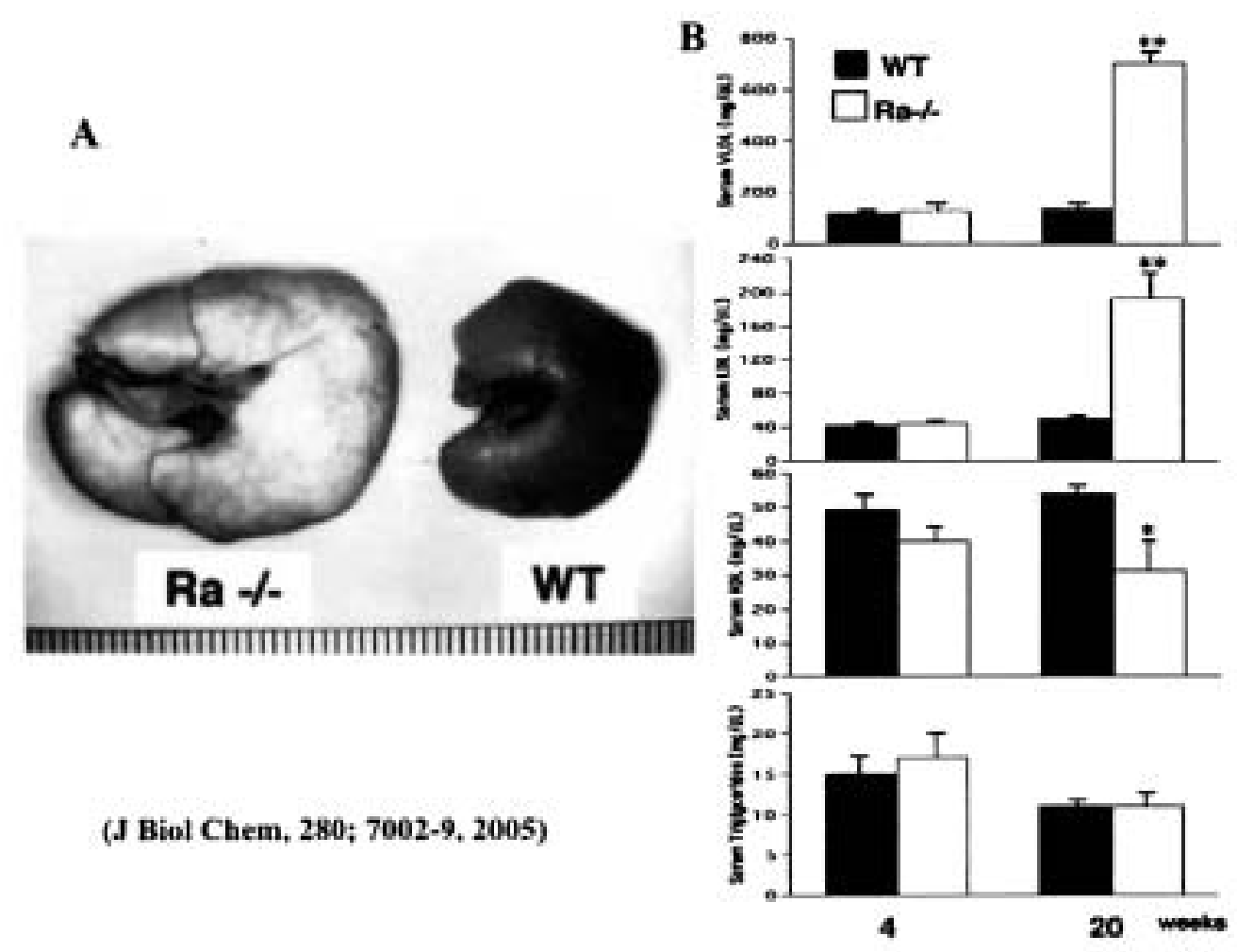

Fig.3. IL-1Ra ${ }^{-/-}$mice showed severe fatty liver and hypercholesterolemia following 20 weeks on an atherogenic diet when compared with IL-1 $\mathrm{Ra}^{+/+}$mice.

A. Macroscopic appearance of livers from IL-1Ra ${ }^{-/-}\left(\mathrm{Ra}^{-/-}\right)$and IL-1Ra ${ }^{+/+}$(WT) mice fed an atherogenic diet for 20 weeks. There was a prominent change in color and size in the liver of IL-1Ra ${ }^{-/-}$ versus IL-1Ra ${ }^{+/+}$mice.

B. Plasma levels of VLDL (upper), LDL (middle upper), HDL (middle lower) and triglycerides (lower) in IL-1 $\mathrm{Ra}^{-/-}\left(\mathrm{Ra}^{-/}\right)$and wild-type (WT) mice. All values are expressed as the mean $+\mathrm{SEM}$. $* p<$ $0.05, * * p<0.01$ for $\mathrm{Ra}^{-/-}$mice versus WT mice.

(VLDL) as a result of adipose tissue lipolysis (49-51). With more severe inflammation, the clearance of VLDL decreases secondary to decreased lipoprotein lipase and apolipoprotein E in VLDL (52-54). LPS and cytokines reduce total serum cholesterol levels in primates, whereas in rodents they increase cholesterol levels by stimulating de novo cholesterol synthesis $(55,56)$, decreasing lipoprotein clearance (57), limiting the conversion of cholesterol to bile acids $(58,59)$, and decreasing the secretion of cholesterol into the bile (60-63). Many of the changes in lipoproteins during inflammation help to protect the host from harmful effects of the stimuli. However, if prolonged, these changes in the structure and function of lipoproteins will contribute to atherogenesis. Of note, inflammatory cytokines are increased and play a pathogenic role in a variety of very common disorders, such as diabetes, obesity, metabolic syndrome, and athero- sclerosis (64-68). Many of these disorders display abnormalities in lipid metabolism that are similar to those that occur during infection and inflammation. However, the effect of chronic inflammation on lipid metabolism has been unclear. Furthermore, there is no report that shows the role of IL-1Ra in the metabolism of cholesterol under chronic inflammatory conditions.

To elucidate the role of IL-1Ra, we fed an atherogenic diet (with cholate) to both IL-1Ra ${ }^{-/ /}$and IL-1Ra ${ }^{+/+}$mice. $\mathrm{IL}-1 \mathrm{Ra}^{-/}$mice developed severe fatty liver after 20 weeks compared to IL-1 Ra ${ }^{++}$mice (Fig. 3A) (69). Histological examination revealed an increase in the number and size of intracellular vacuoles, portal fibrosis, and collagen deposition as well as lobular and portal inflammation in livers of IL-1 $\mathrm{Ra}^{-/-}$mice. Expectedly, the plasma lipid profile became more proatherogenic with increased total cholesterol levels (942 $\pm 160 \mathrm{mg} / \mathrm{dl}$ versus $240 \pm 13 \mathrm{mg} /$ 


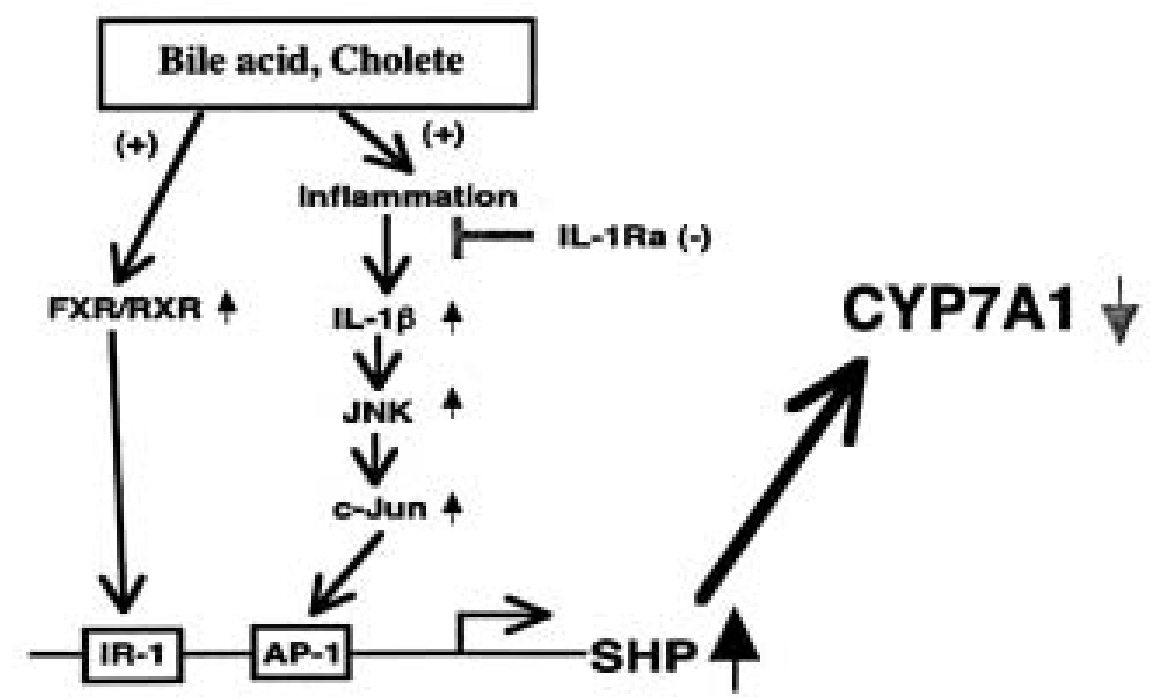

Fig.4. Model for up-regulation of SHP gene expression in the absence of IL-1Ra. Bile acids activate FXR and induce inflammation. The lack of IL-1Ra could not reduce inflammation and might induce the production of a large amount of IL-1. Then IL-1 activated the JNK signaling cascade. Activated FXR and C-Jun enhanced SHP transcription by binding to the IR-1 and AP-1 elements in the SHP promoter. Elevated SHP protein levels in turn repressed CYP7A1 transcription and the down-regulation of CYP7A1 expression increased amounts of bile acids in hepatocytes. Finally this loop formed a vicious circle in the metabolism of bile acids. See text for details.

dl, $n=5 ; p<0.01)$, higher apoB-containing lipoprotein levels $(699 \pm 126 \mathrm{mg} / \mathrm{dl}$ versus $192 \pm 36 \mathrm{mg} / \mathrm{dl} ; p<0.01)$, and decreased HDL levels $(31 \pm 10 \mathrm{mg} / \mathrm{dl}$ versus $54 \pm 3$ $\mathrm{mg} / \mathrm{dl} ; p<0.05)$ in IL-1Ra $\mathrm{Ra}^{-/}$mice compared to IL-1 $\mathrm{Ra}^{+/+}$ mice after 20 weeks on the atherogenic diet (Fig. 3B). Real-time PCR analysis revealed that the decreasein the IL-1Ra mRNA level was accompanied by a increase in the levels of IL- $1 \beta(P<0.001)$, TGF- $\beta(P<0.01)$ and CD68 mRNA $(P<0.001)$ in the IL-1 Ra ${ }^{-/}$liver compared to the WT liver. Furthermore, IL-1Ra ${ }^{-/-}$mice failed to express mRNA of cholesterol $7 \alpha$-hydroxylase (CYP7A1) $(p<0.05)$, the rate-limiting enzyme in bile acid synthesis, with upregulation of small heterodimer partner 1 (SHP) mRNA expression $(p<0.001)$ following 4 weeks on the atherogenic diet (69). Indeed, IL-1 Ra ${ }^{-/}$mice showed markedly decreased bile acid excretion, which is promoted in WT mice to maintain cholesterol levels while feeding on an atherogenic diet. Our results show that both bile acid and high cytokine levels in IL-1Ra ${ }^{-/-}$mice reduced the mRNA expression of CYP7A1 with a upregulation of SHP mRNA expression. We summarize the mechanism of these changes in Fig. 4. Several previous reports demonstrated that administration of cholic acid in mice induced SHP gene expression $(70,71)$ and SHP reduces CYP7A1 expression (72). Increased concentrations of bile acids in the liver could, in turn, induce inflammation and the lack of IL-1Ra, an anti-inflammatory cytokine, might worsen the inflammation in IL-1Ra ${ }^{-/-}$liver. Furthermore, large amounts of cytokines produced in response to severe inflammation in $\mathrm{IL}-1 \mathrm{Ra}^{-/-}$mice could also play an important role in the up-regulation of SHP expression. Cytokine-dependent signaling leads to the activation of C-Jun N-terminal kinase (JNK) and other mitogen-activated protein kinases $(73,74)$. Recently, Gupta et al. showed that C-Jun activated by cytokines induces SHP1 promoter activity and mutations in the AP-1 binding site abolished bile acid responsiveness of the rat SHP promoter (75). Thus, they suggested that activation of the $\mathrm{JNK} / \mathrm{c}$-jun pathway is needed for the induction of SHP by bile acids. Furthermore, Miyake et al. demonstrated that bile acid-induced expression of cytokines (such as TNF- $\alpha$ and IL-1) by macrophages correlates with repression of hepatic CYP7A1 (76), further supporting our findings. Thus, atherogenic diet-induced inflammation with both a high IL-1 level and deficiency of IL-1Ra caused an up-regulation of SHP expression and, in turn, downregulation of CYP7A1. The suppression of CYP7A1 causes more cholesterol to accumulate in $\mathrm{IL}-1 \mathrm{Ra}^{-/}$mice. We conclude that the significant increase in SHP expression in IL-1 Ra ${ }^{-/}$liver is an indirect effect of loss of IL$1 \mathrm{Ra}$, but IL-1Ra plays an important role in maintaining cholesterol homeostasis under conditions of cholic acidinduced inflammation. 


\section{Conclusion}

During the last five years, transgenic and gene knockout studies in murine models of vascular disease have established IL-1 and IL-1Ra as pivotal players in the regulation of vascular cell functions and cholesterol metabolism. Although genetic differences between mouse and man preclude a direct translation of these findings to human disease, these studies have identified several pathways whose perturbation has the potential to significantly shift the balance between disease progression and retardation. An important goal of future studies will be moredetailed investigations of the particular genes and proand anti-inflammatory pathways regulated by different cytokines in atherogenesis and cholesterol metabolism. This challenge could lead to promising novel therapeutic targets for anti-inflammatory therapies, potentially even harnessing some of the sophisticated regulatory systems designed to normally limit the inflammatory response.

Acknowledgments: The authors wish to acknowledge the essential contributions of Drs. Masatoshi Kusuhara, Koji Miyazaki, Makoto Ayaori, Shojiro Sawada, all of the National Defense medical College. We thank the collaborators of our studies for thoughtful instruction and suggestions; Drs. Yoichiro Iwakura, Reiko Horai, and Taizo Matsuki (Institute of Medical Science, University of Tokyo), Dr Mitsuyo Okasaki (Tokyo Medical and Dental University), and Drs Osamu Matsubara and Yutaka Kagata (National Defense Medical College).

We thank Norbert Gerdes (Experimental Cardiovascular Research Karolinska Institute, Stockholm, Sweden) for critical review of the manuscript.

This work was supported in part by a grant from the National Defense Medical College, Tokorozawa, Japan.

\section{References}

(1) Dinarello CA: Biology of interleukin 1. FASEB J, 2: 108-115, 1988

(2) DiGiovine FS and Duff GW: Interleukin-1: the first interleukin. Immunol Today, 11: 13-20, 1990

( 3 ) Tocci, MJ and Schmidt JA: Interleukin-1: Structure and function. In Cytokines in health and disease, second edition. Pp1-27,Marcel Dekker, 1997

( 4 ) Dinarello CA: Interleukin-1, interleukin-1 receptors and interleukin-1 receptor antagonist. Int Rev Immunol, 16: 457-499, 1998

( 5 ) Arend WP: The balance between IL-1 and IL-Ra in disease. Cytokine Growth Factor Rev, 13: 323-340, 2002

( 6 ) Horai R, Asano M, Sudo K, Kanuka H, Suzuki M, Nishihara M, Takahashi M, and Iwakura Y: Production of mice deficient in genes for interleukin (IL)1alpha, IL-1 beta, IL-1alpha/beta, and IL-1receptor antagonist shows that IL-1beta is crucial in turpentine-induced fever development and glucocoticoid secretion. J Exp Med, 187: 1463-1475, 1998

( 7 ) Matsuki T, Horai R, Sudo K, and Iwakura Y: IL-1 plays an important role inlipid metabolism by regulating insulin levels under physiological conditions. J Exp Med, 198: 877-888, 2003

( 8 ) Dzau, VJ, Braun-Dullaeus RC, and Sedding DG: Vascular proliferation and atherosclerosis: New perspectives and therapeutic strategies. Nat Med, 8: 1249-1256, 2002

( 9 ) Bevilacqua MP, Pober JS, Majeau GR, Cotran RS, and Gimbrone MA: Interleukin 1 induces biosynthesis and cell surface expression of procoagulant activity in human vascular endothelial cells. J Exp Med, 160: 618-623, 1984

(10) Libby P, Ordovas JM, Birinyi LK, Auger KR, and Dinarello CA: Inducible interleukin-1 gene expression in human vascular smooth muscle cells. J Clin Invest, 78:1432-1438, 1986

(11) Bevilacqua MP, Pober JS, Wheeler ME, Cotran RS, and Gimbrone MA: Interleukin-1 activation of vascular endothelium. Effects on procoagulant activity and leukocyte adhesion. Am J Pathol, 121: 394403, 1985

(12) Tamaru M, Tomura K, Sakamoto S, Tezuka K, Tamatani T, and Narumi S: Interleukin-1beta induces tissue- and cell type-specific expression of adhesion molecules in vivo. Arterioscler Thromb Vasc Biol, 18: 1292-1303, 1998

(13) Moyer CF, Sajuthi D, Tulli H, and Williams JK: Synthesis of IL-1 alpha and IL-1 beta by arterial cells in atherosclerosis. Am J Pathol, 138: 951-960, 1991

(14) Galea J, Armstrong J, Gadsdon P, Holden H, Francis SE, and Holt CM: Interleukin-1 beta in coronary arteries of patients with ischemic heart disease. Arterioscler Thromb Vasc Biol, 16: 1000-1006, 1996

(15) Ohsuzu F: The roles of cytokines, inflammation and immunity in vascular diseases. J Atheroscler Thromb, 11: 313-321, 2004

(16) Tedgui A and Mallat Z: Anti-inflammatory mechanisms in the vascular wall. Circ Res, 88: 877-887, 2001

(17) Dinarello CA: The role of the interleukin-1-receptor antagonist in blocking inflammation mediated by interleukin-1. N Engl J Med, 343: 732-734, 2000

(18) Dewberry R, Holden H, Crossman D, and Francis $\mathrm{S}$ : Interleukin-1 receptor antagonist expression in human endothelial cells and atherosclerosis. Arterioscler Thromb Vasc Biol, 20: 2394-2400, 2000

(19) Beasley D, McGuiggin ME, and Dinarello CA: Human vascular smooth muscle cells produce an intracellular form of interleukin-1 receptor antagonist. Am J Physiol, 269: C961-C968, 1995

(20) Arend WP: Interleukin-1 receptor antagonist. Adv 
Immunol, 54: 167-227, 1993

(21) Eisenberg SP, Evans R, Arend WP, Verderber E, Brewer MT, Hannum CH, and Thompson RC: Primary structure and functional expression from complementary-DNA of a human interleukn-1 receptor antagonist. Nature, 343: 341-346, 1990

(22) Haskill S, Martin G, Van Le L, Morris J, Peace A, Bigler CF, Jaffe GJ, Hammerberg C, Sporn SA, Fong $S$, Arend WP, and Ralph P: cDNA cloning of an intracellular form of the human interleukin 1 receptor antagonist associated with epithelium. Proc Natl Acad Sci USA, 88: 3681-3685, 1991

(23) Butcher C, Steinkasserer A, Tejura S, and Lennard AC: Comparison of two promoters controlling expression of secreted or intracellular IL-1 receptor antagonist. J Immunol, 153: 701-711, 1994

(24) Andersson J, Bjork L, Dinarello CA, Towbin H, and Andersson U: Lipopolysaccharide induces human interleukin-1 receptor antagonist and interleukin-1 production in the same cell. Eur J Immunol, 22: 2617-2623, 1992

(25) Malyak M, Guthridge JM, Hance KR, Dower SK, Freed $\mathrm{JH}$, and Arend WP: Characterization of a low molecular weight isoforms of IL-1 receptor antagonist. J Immunol, 161: 1997-2003, 1998

(26) Arend WP, Malyak M, Guthridge CJ, and Gabay C: Interleukin-1 receptor antagonist: role in biology. Annu Rev Immunol, 16: 27-55, 1998

(27) Dinarello CA: Interleukin-1 and interleukin-1 antagonism. Blood, 77: 1627-1652, 1991

(28) Dinarello CA: Biologic basis for interleukin-1 in disease. Blood, 87: 2095-2147, 1996

(29) Wang X, Romanic AM, Yue TL, Feuerstein GZ, and Ohlstein EH: Expression of interleukin-1beta, interleukin-1 receptor, and interleukin-1 receptor antagonist mRNA in rat carotid artery after balloon angioplasty. Biochem Biophys Res Commun, 271: 138-143, 2000

(30) Rectenwald JE, Moldawer LL, Huber TS, Seeger JM, and Ozaki CK: Direct evidence for cytokine involvement in neointimal hyperplasia. Circulation, 102: 1697-1702, 2000

(31) Isoda K, Shiigai M, Ishigami N, Matsuki T, Horai R, Nishikawa K, Kusuhara M, Nishida Y, Iwakura Y, and Ohsuzu F: Deficiency of interleukin-1 receptor antagonist promotes neointimal formation after injury. Circulation, 108: 516-518, 2003

(32) Faggin E, Puato M, Zardo L, Franch R, Millino C, Sarinella F, Pauletto $P$, Sartore $S$, and Chiavegato A: Smooth muscle-specific SM22 protein is expressed in the adventitial cells of the ballooninjuryed rabbit carotid artery. Arterioscler Thromb Vasc Biol, 19: 1393-1404, 1999

(33) Li G, Chen S-J, Oparil S, Chen Y-F, and Thompson $J A$ : Direct in vivo evidence demonstrating neointimal migration of adventitial fibroblasts after balloon injury of rat carotid artery. Circulation, 101: 13621365,2000

(34) Sata M, Saiura A, Kunisato A, Tojo A, Okada S, Tokuhisa T, Hirai H, Makuuchi M, Hirata $Y$, and Nagai R: Hematopoietic stem cells differentiate into vascular cells that participate in the pathogenesis of atherosclerosis. Nat Med, 8: 403-409, 2002

(35) Elhage R, Maret A, Pieraggi MT, Thiers JC, Arnal $\mathrm{JF}$, and Bayard F: Differential effects of interleukin1 receptor antagonist and tumor necrosis factor binding protein on fatty-streak formation in apolipoprotein E-deficient mice. Circulation, 97: 242-244, 1998

(36) Devlin CM, Kuriakose G, Hirsch E, and Tabas I: Genetic alterations of IL-1 receptor antagonist in mice affect plasma cholesterol level and foam cell lesion size. Proc Natl Acad Sci U S A, 99: 6280-6285, 2002

(37) Francis SE, Camp NJ, Dewberry RM, Gunn J, Syrris P, Carter ND, Jeffery S, Kaski JC, Cumberland DC, Duff GW, and Crossman DC: Interleukin-1 receptor antagonist gene polymorphism and coronary artery disease. Circulation, 99: 861-866, 1999

(38) Isoda K, Sawada S, Ishigami N, Matsuki T, Miyazaki K, Kusuhara M, Iwakura Y, and Ohsuzu F: Lack of interleukin-1 receptor antagonist modulates plaque composition in apolipoprotein E-deficient mice. Arterioscler Thromb Vasc Biol, 24: 1068-1073, 2004

(39) Kirii H, Niwa T, Yamada Y, Wada H, Saito K, Iwakura $\mathrm{Y}$, Asano M, Moriwaki $\mathrm{H}$ and Seishima M: Lack of Interleukin-1 $\beta$ decreases the severity of atherosclerosis in apoE-deficient mice. Arterioscler Thromb Vasc Biol, 23: 656-660, 2003

(40) Gabay C and Kushner I: Acute-phase proteins and other systemic responses to inflammation. $\mathrm{N}$ Engl J Med, 340: 448-454, 1999

(41) Khovidhunkit W, Kim MS, Memon RA, Shigenaga JK, Moser AH, Feingold KR, and Grunfeld C: Effects of infection and inflammation on lipid and lipoprotein metabolism: mechanisms and consequences to the host. J. Lipid Res, 45: 1169-1196, 2004

(42) Argiles JM, Lopez-Soriano FJ, Evans RD, and Williamson DH: Interleukin-1 and lipid metabolism in the rat. Biochem J, 259: 673-678, 1989

(43) Feingold KR, Soued M, Adi S, Staprans I, Neese R, Shigenaga J, Doerrler W, Moser A, Dinarello CA, and Grunfeld C: Effect of interleukin-1 on lipid metabolism in the rat. Similarities to and differences from tumor necrosis factor. Arterioscler Thromb, 11: 495-500, 1991

(44) Nonogaki K, Fuller GM, Fuentes NL, Moser AH, Staprans I, Grunfeld C, and Feingold KR: Interleukin6 stimulates hepatic triglyceride secretion in rats. Endocrinology, 136: 2143-2149, 1995 
(45) Malmendier CL, Lontie JF, Sculier JP, and Dubois DY: Modifications of plasma lipids, lipoproteins and apolipoproteins in advanced cancer patients treated with recombinant interleukin-2 and autologous lymphokine-activated killer cells. Atherosclerosis, 73: 173-180, 1988

(46) Sherman ML, Spriggs DR, Arthur KA, Imamura K, Frei E 3rd, and Kufe DW: Recombinant human tumor necrosis factor administered as a five-day continuous infusion in cancer patients: phase I toxicity and effects on lipid metabolism. J Clin Oncol, 6: 344-350, 1988

(47) Starnes HF, Jr, Warren RS, Jeevanandam M, Gabrilove JL, Larchian W, Oettgen HF, and Brennan MF: Tumor necrosis factor and the acute metabolic response to tissue injury in man. J Clin Invest, 82: 1321-1325, 1988

(48) Memon RA, Grunfeld C, Moser AH, and Feingold KR: Tumor necrosis factor mediates the effects of endotoxin on cholesterol and triglyceride metabolism in mice. Endocrinology, 132: 2246-2253, 1993

(49) Doerrler W, Feingold KR, and Grunfeld C: Cytokines induce catabolic effects in cultured adipocytes by multiple mechanisms. Cytokine, 6: 478-484, 1994

(50) Zhang HH, Halbleib M, Ahmad F, Manganiello VC, and Greenberg AS: Tumor necrosis factor-alpha stimulates lipolysis in differentiated human adipocytes through activation of extracellular signal-related kinase and elevation of intracellular cAMP. Diabetes, 51: 2929-2935, 2002

(51) Greenberg AS, Shen WJ, Muliro K, Patel S, Souza SC, Roth RA, and Kraemer FB: 2001. Stimulation of lipolysis and hormone-sensitive lipase via the extracellular signal-regulated kinase pathway. J Biol Chem, 276: 45456-45461, 2001

(52) Feingold KR, Marshall M, Gulli R, Moser AH, and Grunfeld C: Effect of endotoxin and cytokines on lipoprotein lipase activity in mice. Arterioscler Thromb, 14: 1866-1872, 1994

(53) Hardardóttir I, Sipe J, Moser AH, Fielding CJ, Feingold KR, and Grünfeld C: LPS and cytokines regulate extra hepatic mRNA levels of apolipoproteins during the acute phase response in Syrian hamsters. Biochim Biophys Acta, 1344: 210-220 1997

(54) Lanza-Jacoby S, Wong SH, Tabares A, Baer D, and Schneider T: Disturbances in the composition of plasma lipoproteins during gram-negative sepsis in the rat. Biochim Biophys Acta, 1124: 233-240, 1992

(55) Feingold KR, Hardardottir I, Memon R, Krul EJ, Moser AH, Taylor JM, and Grunfeld C: Effect of endotoxin on cholesterol biosynthesis and distribution in serum lipoproteins in Syrian hamsters. J Lipid Res, 34: 2147-2158, 1993

(56) Feingold KR, Pollock AS, Moser AH, Shigenaga JK, and Grunfeld C: Discordant regulation of proteins of cholesterol metabolism during the acute phase response. J Lipid Res, 36: 1474-1482, 1995

(57) Xu N and Nilsson A: Endotoxin inhibits catabolism of low density lipoproteins in vivo: an experimental study in the rat. Scand J Clin Lab Invest, 56: 53-61, 1996

(58) Feingold KR, Spady DK, Pollock AS, Moser AH, and Grunfeld C: Endotoxin, TNF, and IL-1 decrease cholesterol 7 alpha-hydroxylase mRNA levels and activity. J Lipid Res, 37: 223-228, 1996

(59) Memon RA, Moser AH, Shigenaga JK, Grunfeld C, and Feingold KR: In vivo and in vitro regulation of sterol 27-hydroxylase in the liver during the acute phase response. Potential role of hepatocyte nuclear factor-1. J Biol Chem, 276: 30118-30126, 2001

(60) Hartmann G, Cheung AK, and Piquette-Miller M: Inflammatory cytokines, but not bile acids, regulate expression of murine hepatic anion transporters in endotoxemia. J Pharmacol Exp Ther, 303: 273-281, 2002

(61) Vos TA, Hooiveld GJ, Koning H, Childs S, Meijer DK, Moshage H, Jansen PL, and Muller M: 199Upregulation of the multidrug resistance genes, Mrp1 and Mdr1b, and down-regulation of the organic anion transporter, Mrp2, and the bile salt transporter, Spgp, in endotoxemic rat liver. Hepatology, 28: 1637-1644, 1998

(62) Tygstrup N, Bangert K, Ott P, and Bisgaard HC: Messenger RNA profiles in liver injury and stress: a comparison of lethal and nonlethal rat models. Biochem Biophys Res Commun, 290: 518-525, 2002

(63) Khovidhunkit W, Moser AH, Shigenaga JK, Grunfeld $C$, and Feingold KR: Endotoxin down-regulates ABCG5 and ABCG8 in mouse liver and ABCA1 and ABCG1 in J774 murine macrophages: differential role of LXR. J Lipid Res, 44: 1728-1736, 2003

(64) Pickup JC and Crook MA: Is type II diabetes mellitus a disease of the innate immune system? Diabetologia, 41: 1241-1248, 1998

(65) Pradhan AD and Ridker PM: Do atherosclerosis and type 2 diabetes share a common inflammatory basis? Eur Heart J, 23: 831-834, 2002

(66) Huerta MG and Nadler JL: Role of inflammatory pathways in the development and cardiovascular complications of type 2 diabetes. Curr Diab Rep, 2: 396-402, 2002

(67) Grimble RF: 2002. Inflammatory status and insulin resistance. Curr Opin Clin Nutr Metab Care, 5: 551559, 2002

(68) Yudkin JS, Kumari M, Humphries SE, and Mohamed-Ali V: Inflammation, obesity, stress and coronary heart disease: is interleukin- 6 the link? Ath- 
erosclerosis, 148: 209-214, 2000

(69) Isoda K, Sawada S, Makoto A, Matsuki T, Horai R, Kagata Y, Miyazaki K, Kusuhara M, Okazaki M, Matsubara O, Iwakura Y, and Ohsuzu F: Deficiency of interleukin-1 receptor antagonist deteriorates fatty liver cholesterol metabolism in hypercholesterolemic mice. J Biol Chem, 280: 7002-7009, 2005

(70) Lu TT, Makishima M, Repa JJ, Schoonjans K, Kerr TA, Auwerx J, and Mangelsdorf DJ: Molecular basis for feedback regulation of bile acid synthesis by nuclear receptors. Mol Cell, 6: 507-515, 2000

(71) Goodwin B, Jones SA, Price RR, Watson MA, McKee DD, Moore LB, Galardi, C, Wilson JG, Lewis MC, Roth ME, Maloney PR, Willson TM, and Kliewer $S A$ : A regulatory cascade of the nuclear receptors FXR, SHP-1, and LRH-1 represses bile acid biosynthesis. Mol Cell, 6: 517-526, 2000

(72) Bohan A, Chen WS, Denson LA, Held MA, and Boyer $\mathrm{JL}$ : Tumor necrosis factor $\alpha$-dependent up-regulation of Lrh-1 and Mrp3(Abcc3) reduces liver injury in obstructive cholestasis. J Biol Chem, 278: 3668836698, 2003

(73) Li X, Commane M, Burns C, Vithalani K, Cao Z, and
Stark GR: Mutant cells that do not respond to interleukin-1 (IL-1) reveal a novel role for IL-1 receptor-associated kinase. Mol Cell Biol, 19: 46434652, 1999

(74) Lomaga MA, Yeh WC, Sarosi I, Duncan GS, Furlonger C, Ho A, Morony S, Capparelli C, Van G, Kaufman S, van der Heiden A, Itie A, Wakeham A, Khoo W, Sasaki T, Cao Z, Penninger JM, Paige CJ, Lacey DL, Dunstan CR, Boyle WJ, Goeddel DV, and Mak TW: TRAF6 deficiency results in osteopetrosis and defective interleukin-1, CD40, and LPS signaling. Genes Dev, 13: 1015-1024, 1999

(75) Gupta S, Stravitz RT, Dent P, and Hylemon PB: Down-regulation of cholesterol 7alpha-hydroxylase (CYP7A1) gene expression by bile acids in primary rat hepatocytes is mediated by the c-Jun N-terminal kinase pathway. J Biol Chem, 276: 1581615822, 2001

(76) Miyake JH, Wang S-L, and Davis RA: Bile acid induction of cytokine expression by macrophages correlates with repression of hepatic cholesterol 7alpha-hydroxylase. J Biol Chem, 275: 2180521808, 2000 